\title{
Елканова Т.М.
}

\section{Гуманитаризация образования: проблемы и задачи}

\author{
Elkanova T.M. \\ Humanitarization of education: problems and challenges
}

Для решения проблемы гуманитаризации образования необходимы: выявление степени соотношения понятий «гуманизация» и «гуманитаризация» и их проецирование на задачи образовательного процесса в контексте современной исторической эпохи; выделение, обобщение и систематизация основных принципов и целей гуманитаризации; создание соответствующей образовательной среды; разработка структуры и содержания общегуманитарного базиса образования

Ключевые слова: высшее образование, гуманитаризация, общегуманитарный базис

\section{Елканова Тамара Михайловна}

Кандидат физико-математических наук, доцент Северо-Осетинский государственный университет им. К.Л. Хетагурова

2. Владикавказ, ул. Ватутина, 44-46
To solve the problem of humanitarization of education is needed: to determine the degree of correlation of concepts "humanization" and" humanitarization" and their projection on the tasks of the educational process in the context of contemporary historical epoch; selection, generalization and systematization of basic principles and goals of humanitarization; the establishment of appropriate educational environment; development of the structure and content of the general humanitarian basis of education

Key words: higher education, humanitarization, general humanitarian basis
Elkanova Tamara Michailovna
Candidate of Physico-mathematical Sciences, Associate Professor
North-Ossetian state university named K.L. Khetagurov
Vladikavkaz, Vatutina st., 44-46

В XXI веке, названном ЮНЕСКО «веком человеческого фактора», значительно возрастает роль не только профессиональной грамотности и компетентности специалиста любого уровня, но и его нравственно-этических качеств, сформированности и устойчивости чувства ответственности за социально-экологические аспекты своей деятельности. Именно поэтому особую актуальность приобретают гуманизация и гуманитаризация общего и профессионального образования, направленные прежде всего на формирование личности специалиста, обладающего не только развитыми профессиональными компетенциями, но и поликультурным кругозором и гуманитарной грамотностью, способного к целостному и системному анализу сложных проблем современной жизни общества и окружающей среды. Проблема гуманитаризации приобретает особо приоритетный характер в условиях перестройки российской системы образования в соответствии с компетентностным подходом, результативно-целевой основой которого является система ключевых компе- 
тенций. Мы считаем, что формирование таких компетенций возможно только при условии гуманизации и гуманитаризации системы образования, что с неизбежностью приводит к необходимости создания соответствующей образовательной среды [1]. Это требует от системы образования кардинального реформирования его структуры, пересмотра содержания учебных планов, насыщения программ новыми презентативно-значимыми образовательными курсами, усиления антропогностического аспекта в преподавании учебных дисциплин.

Проведенный нами анализ степени изученности проблемы гуманитаризации профессионального образования позволяет заключить, что, несмотря на очевидный интерес к проблеме гуманитаризации образования, до сих пор не сформулирована целостная система психолого-педагогических принципов развития гуманитарной направленности личности студентов, не выявлены конкретные способы ее комплексной реализации. Поэтому мы считаем необходимым произвести выделение, обобщение и систематизацию основных принципов и целей гуманитаризации.

Многочисленные исследования процесса гуманитаризации образования, проводившиеся в течение продолжительного времени, показывают многогранность и сложность темы. Однако в настоящее время в работах, посвященных гуманизации и гуманитаризации образования, феномены гуманизации и гуманитаризации нередко трактуются произвольно, часто отождествляются и подменяются друг другом, в то время как, несмотря на их семантическое родство, они имеют различное философское и педагогическое содержание. В этой связи интересно обратиться к выявлению степени соотношения таких понятий, как «гуманизация» и «гуманитаризация». Особенностью данных понятий является их социокультурная и историческая изменчивость: они формируются заново в каждую новую историческую эпоху, меняя свою онтологическую нагруженность. Целесообразно спроецировать данные термины на задачи образовательного процесса в контексте современной исторической эпохи.

Гуманитаризация - не специфически отечественное, а мировое явление, в котором отражаются общие глобальные процессы. Прежде всего, она направлена на поворот образования к целостной картине мира, на формирование гуманитарного и системного мышления. В мировой практике гуманитаризация осуществляется в основном путем введения в учебный процесс широкого спектра обязательных и элективных курсов гуманитарного и интегративномеждисциплинарного характера. На наш взгляд, гуманитаризация как акцент на преобладании роли гуманитарных дисциплин неприемлема по сути. Мы считаем, что цели и задачи гуманитаризации образования заключаются в возвращении его исторического и содержательного - к человеку обращенного основания каждому учебному предмету. Речь идет о переориентации преподавания базовых и элективных дисциплин с объективно-безличного изложения знаний на определение их места и роли в социокультурном контексте эпохи, на основе изучения объектов познания в системе «природа - наука - техника общество - человек». Необходимо придать не только гуманный характер формам и методам обучения, но и исторически рефлексивный смысл самому со- 
держанию образования. На этой научной основе и понимается нами гуманитаризация учебного познания.

Проведенный нами системный компаративный анализ принципов и целей гуманитаризации [5] привел нас к разработке концептуальнотеоретической модели общегуманитарного базиса современного образования путем интегративно-содержательного подхода к формированию его структуры вне зависимости от частно-методических целей и направлений конкретных образовательных курсов [2, 3]. Необходимым условием эффективной гуманитаризации процесса обучения мы считаем создание соответствующей образовательной среды. В научно-педагогической литературе достаточно полно рассмотрены, хотя и недостаточно конкретизированы в практическом плане, модели гуманитарной образовательной среды в учебном заведении как целостной образовательной структуре. Мы предлагаем концепцию создания локальной гуманитарно-развивающей образовательной среды непосредственно при изучении отдельных учебных дисциплин, опираясь на определение среды как зоны непосредственной активности индивида, его ближайшего развития и действия [4].

Полагаем, что требование скорелированности образовательного вектора с тенденциями общецивилизационного развития, учета переживаемых обществом цивилизационных проблем обусловлено диссипативной основой образовательной системы, поэтому основа концепции гуманитаризации образования состоит в ориентации образования на решение задач, находящихся в поле современной цивилизации и культуры. В силу этого является очевидной необходимость разработки инновационной системы образования, отвечающей императиву гуманитаризации, выступающей общеметодологическим ориентиром развития образовательной среды и построения единого культуросообразного образовательного пространства.

\section{Список используемых источников:}

1. Елканова Т.М. Современная образовательная среда: понятие и педагогическая сущность // European Social Science Journal. 2014. №8. T. 2. C. 38-43.

2. Елканова Т.М. Общегуманитарный базис образования: структурные компоненты: Монография.

Владикавказ: Олимп, 2013. 156 с.

3. Елканова Т.М. Общегуманитарный базис образования: структура и содержание // European Social Science Journal. 2014. №3. T. 2. C. 46-52.

4. Елканова Т.М. Концептуальная модель локальной гуманитарно-развивающей образовательной среды // Высшее образование сегодня. 2009. №7. С. 56-59.

5. Elkanova T.M., Chedzhemova N.M. Humanization and Humanitarization of Education: The Essence, Principles, Aims // World Applied Sciences Journal 22 (5): 697-702, 2013. DOI:

10.5829/idosi.wasj.2013.22.05.13175.

(C) 2015, Елканова Т.M.

Гуманитаризация образования: проблемы и задачи
(C) 2015, Elkanova T.M.

Humanitarization of education: problems and challenges 